\title{
EKSISTENSI INDUSTRI TEPUNG IKAN DI KOTA TEGAL, JAWA TENGAH
}

\author{
Erlania \\ Pusat Penelitian dan Pengembangan Perikanan Budidaya \\ JI. Ragunan 20 Pasar Minggu, Jakarta Selatan 12540 \\ E-mail: erlania_elleen@ yahoo.com
}

\begin{abstract}
ABSTRAK
Ketergantungan industri pakan ikan terhadap bahan baku impor, termasuk tepung ikan, menyebabkan harga pakan ikan menjadi mahal, sementara produksi tepung ikan lokal belum dapat memenuhi kebutuhan industri pakan, baik dari segi kualitas maupun kuantitas. Kota Tegal, Jawa Tengah merupakan daerah penghasil ikan dengan hasil tangkapan yang masih berlimpah, sehingga di daerah ini industri tepung ikan cukup berkembang walaupun masih dengan teknologi yang sangat sederhana. Industri tepung ikan yang berkembang di kawasan pengolahan ikan di pelabuhan perikanan Kota Tegal ini menggunakan bahan baku yang berasal dari limbah industri fillet berupa kepala, tulang, kulit, sisik, jeroan, dan sisasisa daging ikan yang menempel pada tulang. Kekurangan dari tepung ikan lokal, termasuk dari Tegal umumnya memiliki kualitas rendah dengan kandungan protein antara 37\%38\%dan kadar abu yang cukup tinggi yaitu $42 \% 44 \%$ (tidak memenuhi standar mutu tepung ikan berdasarkan SNI 012715-1996/Rev. 92). Hal ini disebabkan karena rendahnya kualitas bahan baku yang digunakan. Agar produk tepung ikan lokal dapat bersaing dengan tepung ikan impor, maka perlu adanya upaya peningkatan kualitas tepung ikan melalui penggunaan bahan baku dan penerapan teknologi yang lebih baik, sehingga dapat mereduksi penggunaan tepung ikan impor khususnya dalam industri pakan ikan.
\end{abstract}

\section{KATA KUNCl: industri, tepung ikan, Kota Tegal, Jawa Tengah}

\section{PENDAHULUAN}

Salah satu komponen dari berbagai jenis bahan baku dalam pembuatan pakan ikan adalah tepung ikan. Tepung ikan digunakan sebagai sumber protein utama selain tepung bungkil kedelai. Ketergantungan industri pakan ikan terhadap bahan baku impor, termasuk tepung ikan, menyebabkan harga pakan ikan semakin mahal, terutama di tingkat petani/pembudidaya ikan. Sementara, nilai jual ikan, khususnya ikan air tawar relatif stabil dan tidak sebanding dengan kenaikan harga pakan. Hal ini berdampak pada semakin rendahnya profit yang diperoleh pembudidaya ikan. Untuk jangka panjang, kondisi seperti ini akan mempengaruhi keberlanjutan usaha budidaya masyarakat terutama pembudidaya dengan skala usaha menengah ke bawah.

Saat ini, produksi tepung ikan lokal belum dapat memenuhi kebutuhan industri pakan ikan, baik dari segi kualitas maupun kuantitas. Menurut Anonim (2012), industri perikanan nasional membutuhkan minimal 150.000 ton tepung ikan setiap tahun guna mereduksi ketergantungan bahan baku pakan yang masih didominasi melalui mekanisme impor. Ketua Bidang Akuakultur Asosiasi Produsen Pakan Indonesia mengungkapkan bahwa kapasitas produksi tepung ikan di Indonesia hanya sekitar 45.000 ton atau 30\%dari total kebutuhan setiap tahun. Hingga saat ini Indonesia masih sangat mengandalkan tepung ikan impor dari Thailand dan Vietnam. Akibatnya, industri pakan besar yang membutuhkan pasokan bahan baku yang kontinu memilih untuk menggunakan tepung ikan impor.

Selain terpenuhinya kontinuitas, tepung ikan impor juga memiliki kualitas yang jauh lebih baik dibandingkan tepung ikan lokal. Menurut Basir et al. (1996), industri pakan besar lebih menyukai produk impor dengan pertimbangan kualitasnya lebih terjamin, di mana kualitas tepung ikan impor lebih baik dari tepung ikan lokal, karena nilai proteinnya lebih dari 45\%dan kandungan lemaknya kurang dari $10 \%$ serta kandungan $\mathrm{NaCl}$-nya kurang dari $3 \%$

Pengembangan industri tepung ikan lokal merupakan salah satu solusi untuk dapat mengatasi ketergantungan industri pakan terhadap pasokan tepung ikan impor. Ketersediaan sumberdaya ikan di perairan Indonesia masih dapat diandalkan untuk mendukung industri tepung ikan dalam negeri (Gambar 1). Menurut data M MAF-JICA 


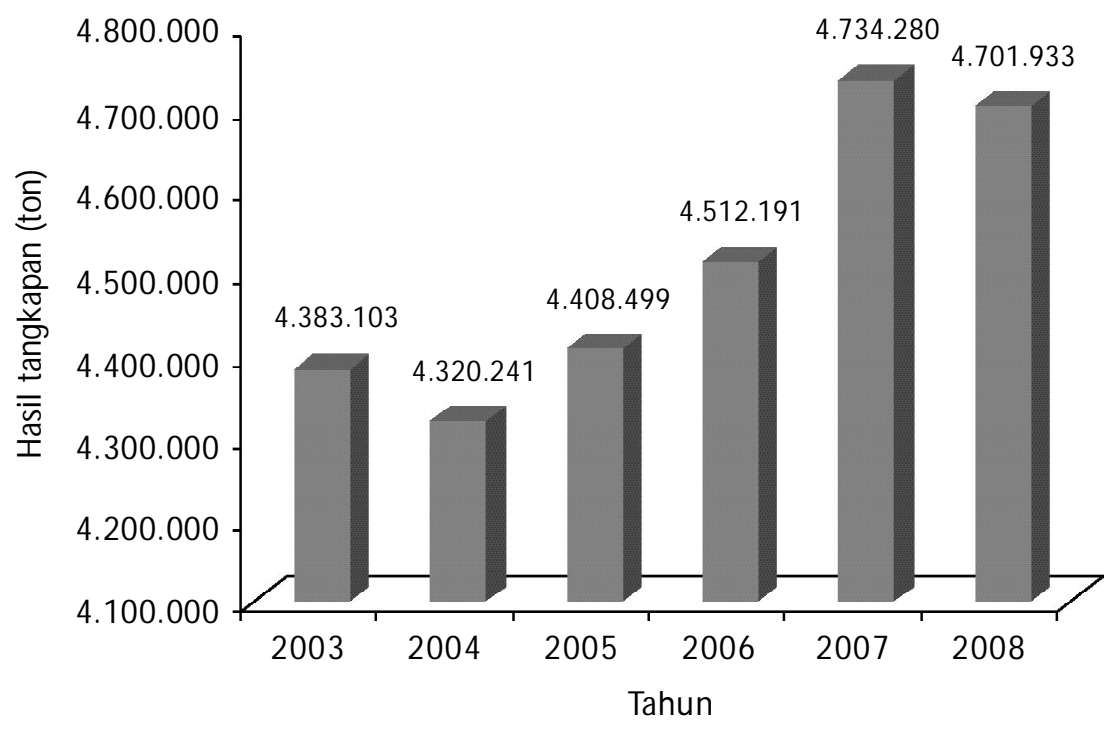

Gambar 1. Produksi perikanan tangkap nasional (perairan laut dan darat/ inland open water) (Sumber: MMAF-JICA, 2010)

(2010), potensi wilayah penangkapan ikan nasional untuk perairan laut mencapai 5,8 juta $\mathrm{km}^{2}$; dengan potensi lestari (Maximum Sustainable Yield/MSY) sebesar 6,4 juta ton/ tahun; Total Allowable Catch (TAC) 5,12 juta ton/tahun (80\%MSY); sedangkan produksi hasil tangkapan pada tahun 2008 baru mencapai 4,70 juta ton.

Dengan ketersediaan potensi tangkapan yang masih memadai, dalam optimalisasi pemanfaatannya perlu adanya campur tangan pemerintah untuk mengatur seberapa besar produksi perikanan tangkap yang dapat dialokasikan untuk industri tepung ikan dan untuk konsumsi nasional maupun ekspor.

\section{Potensi Bahan Baku dan Prospek Pengembangan Industri Tepung Ikan di Kota Tegal}

Kota Tegal, Jawa Tengah merupakan daerah penghasil ikan yang sebagian besar berasal dari hasil penangkapan. Produksi perikanan tangkap di Kota Tegal menunjukkan peningkatan dari tahun ke tahun. Produksi perikanan tangkap Kota Tegal pada tahun 2003 sebesar 3.197 ton, meningkat pada tahun 2005 menjadi 3.580 ton; dan pada tahun 2008 mencapai 5.458 ton (Anonim, 2010) dari total produksi perikanan tangkap Provinsi Jawa Tengah sebesar 192.172 ton pada tahun 2008 (M MAF-JICA, 2010). Kondisi ini menjadi salah satu faktor yang mendorong berkembangnya industri tepung ikan di daerah tersebut, karena dengan kondisi tersebut kebutuhan bahan baku akan dapat terpenuhi. Masih rendahnya pemanfaatan ikan untuk bahan baku industri tepung ikan di Tegal, menjadikan peluang pengembangan industri tepung ikan di daerah ini semakin besar. Selain itu, tepung ikan merupakan komoditas yang memiliki peluang pasar yang cukup besar, terutama untuk memenuhi kebutuhan industri pakan menggantikan tepung ikan impor.

Industri pengolahan ikan (termasuk industri tepung ikan) yang berkembang di Tegal, lokasinya terpusat pada kawasan pengolahan ikan di pelabuhan perikanan Kota Tegal. Pada lokasi tersebut terdapat cold storage dan industri fillet ikan yang dikelola oleh kelompok/koperasi. Limbah atau sisa-sisa pengolahan ikan yang dihasilkan dari industri fillet jumlahnya cukup banyak sehingga dapat dimanfaatkan oleh masyarakat sebagai bahan baku tepung ikan; baik berupa kepala, tulang, kulit, sisik, jeroan, dan sisa-sisa daging ikan yang menempel pada tulang. Selain itu, di area tersebut juga terdapat ikan-ikan hasil tangkapan yang tidak laku dijual untuk konsumsi masyarakat karena kualitasnya kurang baik; ikan-ikan seperti ini umumnya dikenal dengan istilah by-catch atau hasil tangkap sampingan/HTS (Ariyawansa, 2000); yang juga dimanfaatkan sebagai bahan baku industri tepung ikan. Bahan baku tersebut diperoleh oleh pengusaha tepung ikan dengan harga rata-rata Rp 1.000,-/kg. Menurut Windsor (2001), di beberapa negara seperti Inggris, tepung ikan dibuat dari ikan-ikan yang tidak terjual dan sisa-sisa ikan yang tidak dimakan seperti kepala, tulang dan serpihan daging yang tersisa saat dilakukan pemotongan untuk mengambil bagian yang dapat dimakan. Sedangkan di Denmark dan Islandia, industri tepung ikan menggunakan bahan baku baik berupa ikan hasil tangkapan maupun limbah industri pengolahan ikan.

Ikan-ikan yang digunakan untuk pembuatan tepung ikan ada yang masih tawar dan ada juga yang sudah 
diasinkan. Tepung ikan yang asin harganya lebih murah dibandingkan tepung ikan tawar. Tepung ikan yang siap dipasarkan terdiri atas dua jenis yaitu tepung ikan yang masih kasar (belum digiling) dan yang sudah halus. Tepung ikan tawar yang masih kasar dijual dengan harga Rp 4.000,-/kg, sedangkan yang sudah digiling harga jualnya Rp 5.000,--kg.

Usaha pengolahan tepung ikan di kawasan pelabuhan perikanan Tegal ini umumnya masih tergolong usaha skala kecil. Limbah pengolahan ikan yang dihasilkan dari industri fillet memiliki kuantitas yang cukup besar, sehingga industri tepung ikan yang berada di kawasan ini mampu menghasilkan tepung ikan dengan kapasitas produksi rata-rata antara 4-5 kwintal/minggu. Pemasaran tepung ikan dari wilayah ini mencakup daerah Jakarta, Surabaya, dan Jombang. Pembeli umumnya terlebih dahulu memesan tepung ikan sesuai dengan kondisi dan kuantitas yang dibutuhkan, sehingga pemilik usaha tersebut dapat menyediakan tepung ikan dalam jangka waktu tertentu sebagaimana permintaan pembeli, namun tetap dibatasi oleh kapasitas produksi yang mereka miliki.

\section{Proses Pengolahan Tepung Ikan}

Proses pembuatan tepung ikan pada industri di kawasan ini dilakukan dengan teknik tradisional dan sarana pengolahan yang sangat sederhana. Bahan baku dimasukkan ke dalam wadah perebusan berukuran $2 \mathrm{~m} \mathrm{x}$ $3 \mathrm{~m}$, kemudian direbus di atas tungku menggunakan kayu bakar. Ikan yang sudah direbus selanjutnya dijemur di bawah sinar matahari dengan media penjemuran terbuat dari bambu. Setelah ikan-ikan tersebut kering, kemudian dihaluskan dengan menggunakan mesin penggiling hingga menjadi tepung (Gambar 2). Tepung ikan yang dihasilkan dari proses penggilingan tersebut sudah siap untuk dipasarkan (Gambar 3). Sebagaimana dinyatakan oleh Windsor (2001) bahwa tepung ikan dibuat dari ikan maupun sisa-sisa/limbah pengolahan ikan melalui proses pengeringan, penggilingan atau proses lainnya tanpa penggunaan bahan tambahan.
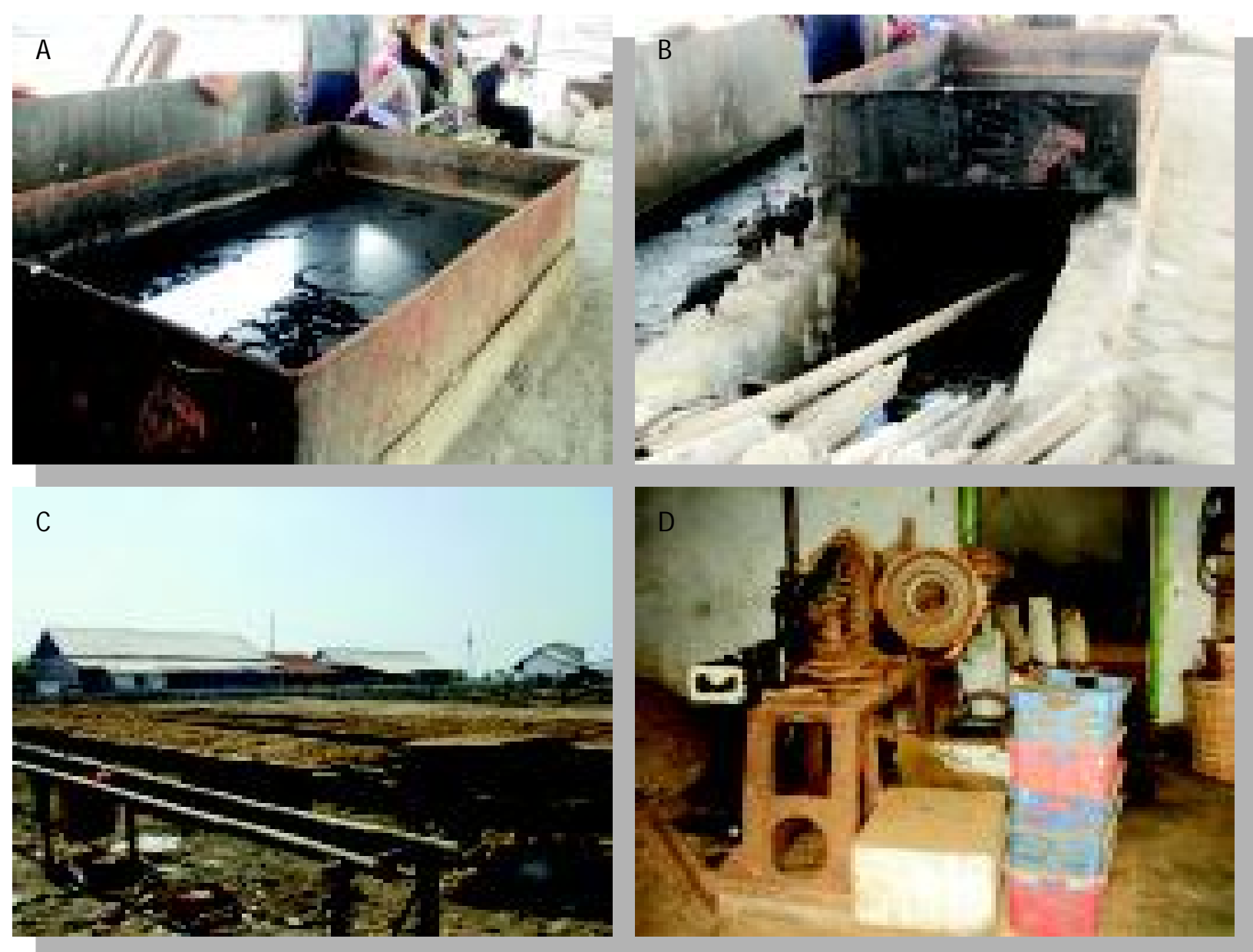

Gambar 2. Proses pengolahan tepung ikan di Kota Tegal, (A) wadah perebusan, (B) tungku, (C) penjemuran, (D) penggilingan 


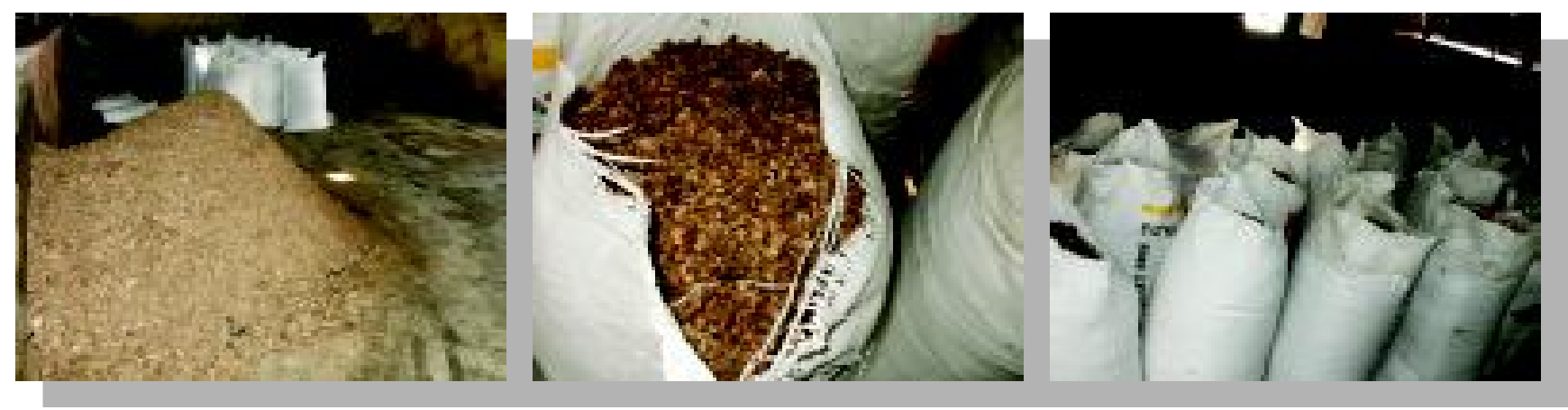

Gambar 3. Produk tepung ikan yang dihasilkan dan siap dipasarkan

\section{Keterbatasan Tepung Ikan Lokal}

Hingga saat ini, industri tepung ikan di daerah-daerah di Indonesia sampai saat ini belum terlalu banyak berkembang, sehingga belum dapat memenuhi kebutuhan tepung ikan dalam negeri. Sebagian besar industri tepung ikan berada di daerah Muncar, Banyuwangi (Jawa Timur) di mana di daerah tersebut terdapat sekitar 20 usaha/ industri tepung ikan; dan di daerah Jembrana (Bali) sedikitnya terdapat 10 usaha/industri yang sama (Widodo, 2008). Selain kuantitas yang masih terbatas, tepung ikan lokal juga memiliki keterbatasan dalam hal kualitas. Kandungan nutrien dari tepung ikan lokal jauh lebih rendah dibandingkan dengan tepung ikan impor. Berdasarkan hasil analisis laboratorium, produk tepung ikan yang dihasilkan dari industri tepung ikan di Kota Tegal kandungan proteinnya berkisar 37\%38\%(Tabel 2). Nilai tersebut masih di bawah standar mutu tepung ikan berdasarkan SNI 01-2715-1996/Rev. 92 tentang Tepung Ikan/Bahan Baku Pakan (Tabel 1) yaitu kandungan protein untuk standar mutu I, II, dan III adalah 65\% 55\% dan 45\% Sementara itu, tepung ikan impor memiliki kandungan protein berkisar antara 64,1\%73\% (Catacutan, 2002), karena secara umum jaringan tubuh ikan mengandung protein berkisar antara $65 \% 75 \%$ (bobot kering) (Millamena, 2002). Oleh karena itu, industri pakan cenderung lebih memilih untuk menggunakan tepung ikan impor, karena selain dapat tersedia secara kontinu, kandungan proteinnya juga lebih tinggi, sehingga jumlah yang digunakan dalam formulasi pakan juga lebih sedikit untuk mendapatkan pakan dengan kadar protein tertentu, jika dibandingkan dengan penggunaan tepung ikan lokal.

Rendahnya kualitas tepung ikan lokal salah satunya disebabkan karena kualitas bahan baku yang digunakan juga relatif kurang baik, umumnya berupa limbah industri fillet dan ikan-ikan kualitas rendah yang sudah tidak dimanfaatkan. Menurut Windsor (2001), kebanyakan industri tepung ikan dunia menggunakan whole fish sebagai bahan baku, umumnya ikan-ikan pelagis yang dimanfaatkan untuk tujuan tersebut. Namun demikian, menurut Ariyawansa (2000), ikan yang dijadikan bahan baku tepung ikan memang digolongkan atas tiga kategori yaitu ikan tangkapan yang diperuntukkan untuk industri tepung ikan, ikan-ikan sisa dari hasil tangkapan (by-catch) dan limbah pengolahan ikan. Kategori bahan baku yang berbeda akan menghasilkan tepung ikan dengan kualitas yang berbeda. Selain itu, menurut Ariyawansa (2000), penanganan (handling) bahan baku juga berpengaruh terhadap kualitas produk yang dihasilkan. Pendinginan dan pemberian es untuk menjaga kesegaran bahan baku akan memperlambat proses penguraian biologis oleh bakteri, sehingga dapat mencegah penurunan kandungan nutrien bahan.

Selain kadar protein yang masih di bawah mutu standar III, kandungan abunya juga terlalu tinggi yaitu sekitar $42 \%$ 44\% Sementara itu, kadar abu maksimum untuk tepung ikan berdasarkan SNI adalah maksimum 20\% 25\% dan $30 \%$ untuk mutu I, II, dan III. Tingginya kadar abu disebabkan karena bahan baku yang digunakan lebih

Tabel 1. SNI tepung ikan/bahan baku pakan (SNI 01-2715-1996/Rev. 92)

\begin{tabular}{lccccc}
\hline \multirow{2}{*}{ Persyaratan } & Kadar air & Protein & Serat kasar & Abu & Lemak \\
\cline { 2 - 6 } & Maksimal & Minimal & Maksimal & Maksimal & Maksimal \\
\hline M utu I & 10 & 65 & 1,5 & 20 & 8 \\
M utu II & 12 & 55 & 2,5 & 25 & 10 \\
M utu III & 12 & 45 & 3 & 30 & 12 \\
\hline
\end{tabular}


Tabel 2. Nutrisi tepung ikan dari kawasan industri tepung ikan di Kota Tegal

\begin{tabular}{lcc}
\hline \multirow{2}{*}{$\begin{array}{c}\text { Analisis proksimat } \\
\text { (\%bobot kering) }\end{array}$} & \multicolumn{2}{c}{ Industri } \\
\cline { 2 - 3 } & A & B \\
\hline Kadar air & 5,00 & 8,30 \\
Protein & 38,68 & 37,19 \\
Lemak & 7,89 & 12,00 \\
Abu & 44,79 & 42,37 \\
Serat kasar & 5,66 & 4,79 \\
BETN & 2,98 & 3,65 \\
\hline
\end{tabular}

dominan berupa kepala dan tulang ikan dari limbah industri fillet.

\section{PENUTUP}

Untuk memenuhi kebutuhan nasional terhadap tepung ikan, maka perlu dilakukan pengembangan industri tepung ikan lokal. Upaya tersebut membutuhkan dukungan yang cukup serius dari pemerintah. Mengingat besarnya nilai impor tepung ikan untuk memenuhi kebutuhan industri pakan nasional, sehingga sedemikian besar pula kebutuhan tepung ikan yang harus dipenuhi oleh industri tepung ikan dalam negeri.

Agar produk tepung ikan lokal dapat bersaing dengan dengan tepung ikan impor, maka perlu adanya upaya untuk peningkatan kualitas tepung ikan melalui penggunaan bahan baku yang juga lebih baik. Perlunya campur tangan pemerintah, terutama dalam mengatur pengalokasian jumlah dan jenis ikan yang dihasilkan dari sektor perikanan tangkap untuk digunakan dalam industri tepung ikan maupun untuk konsumsi manusia. Dengan demikian, industri tepung ikan dapat dikembangkan dengan ketersediaan bahan baku yang berkualitas dan kontinu, tanpa mengurangi ketersediaan/stok ikan untuk kebutuhan konsumsi masyarakat dan untuk perdagangan, baik dalam maupun luar negeri (ekspor). Keberadaan kawasan industri tepung ikan skala kecil di Kota Tegal, Jawa Tengah ini diharapkan dapat dijadikan sebagai salah satu contoh sederhana dalam pengembangan industri tepung ikan lokal di daerah-daerah potensial lainnya di Indonesia.

\section{UCAPAN TERIMA KASIH}

Ucapan terima kasih disampaikan kepada Prof. Ris. Dr. Achmad Sudradjat yang telah memfasilitasi pengambilan data dan analisis sampel dari kegiatan riset APBN tahun anggaran 2010, Puslitbang Perikanan Budidaya.

\section{DAFTAR ACUAN}

Anonim. 2010. Prospek Pengolahan Tepung Ikan di Kota Tegal. http://bisnisukm.com/potensi-perikanan-dikota-tegal.html. Diakses tanggal 20 Oktober 2010.

Anonim. 2012. Bahan Baku Pakan: Indonesia Butuh 150.000 Ton Tepung Ikan per Tahun. Indonesian Aquaculture Society. http://www.aquaculture-mai.org. Diakses tanggal 02 Juli 2012.

Ariyawansa, S. 2000. The Evaluation of Functional Properties of Fish Meal. UNU-Fisheries Training Programme. Srilanka, 25 pp.

Basir, S., Kartasanjaya, \& Soeryono. 1996. Pengaruh Lama Pemasakan dan Tinggi Penekanan terhadap Kadar Protein dan Lemak pada Pembuatan Tepung Ikan. Bull. Lit. Bang. Industri, 21: 3-36.

Ministry of Marine Affairs and Fisheries-Japan International Cooperation Agency [M M AF-JICA]. 2010. Indonesian Fisheries Book 2010. JICA Fisheries Planning And Management, $86 \mathrm{hlm}$.

Millamena, O.M. 2002. The Essential Nutrients. In: Millamena et al. (Eds.) Nutrition in Tropical Aquaculture. Essentials of Fish Nutrition, Feed, and Feeding of Tropical Aquatic Species. SEAFDEC. Tigbauan, Iloilo, Phillippines, p. 8-75.

Catacutan, M.R. 2002. Formulation of Aquafeeds. In: Millamena et al. (Eds.) Nutrition in Tropical Aquaculture. Essentials of Fish Nutrition, Feed, and Feeding of Tropical Aquatic Species. SEAFDEC. Tigbauan, Iloilo, Phillippines, p. 99-123.

Widodo, W. 2008. Ketahanan Pakan Unggas di Tengah Krisis Pangan. Orasi Pengukuhan Guru Besar dalam Bidang Ilmu Nutrisi dan Makanan Ternak Unggas. Fakultas Peternakan-Perikanan, Universitas Muhammadiyah Malang, $46 \mathrm{hlm}$.

Windsor, M.L. 2001. Fish Meal. FAO in Partnership with Support Unit for International Fisheries and Aquatic Research, SIFAR. Torry Advisory Note No. 49. Torry Research Station, 9 pp. 